\title{
Editorial
}

\section{Obesity, a health burden of a global nature}

\author{
Zhi-yun ZHANG, Ming-wei WANG* \\ The National Center for Drug Screening and the State Key Laboratory of Drug Research, Shanghai Institute of Materia Medica, Chinese \\ Academy of Sciences, Shanghai 201203, China
}

Acta Pharmacologica Sinica (2012) 33: 145-147; doi: 10.1038/aps.2011.185

Obesity, the primary health threat in the 21st century, affects the quality of life physiologically, economically and psychologically, irrespective of cultural, financial or ethnic background. Prevalence of obesity has been increasing steadily during the past 30 years worldwide, especially in developed countries. In America, almost one-third of adult population are obese $\left(B M I \geq 30 \mathrm{~kg} / \mathrm{m}^{2}\right)^{[1]}$ and healthcare expenditure for obesity had reached nearly 75 billion USD in $2003^{[2]}$. A similar picture has been seen in developing countries as well where incidence of obesity is rising at an alarming speed. In China, according to one report, $12.1 \%$ and $2.6 \%$ of the urban population are either overweight $\left(25 \mathrm{~kg} / \mathrm{m}^{2} \leq \mathrm{BMI} \leq 30 \mathrm{~kg} / \mathrm{m}^{2}\right)$ or clinically obese $\left(B M I \geq 30 \mathrm{~kg} / \mathrm{m}^{2}\right)^{[3]}$. The situation in children is more disturbing: a 2005 study conducted in northern coastal large cities of China shows that the combined prevalence of obesity had reached $32.5 \%$ in boys and $17.6 \%$ in girls, respectively ${ }^{[4]}$. Possible contributing factors may include steady economic growth, lifestyle changes and significantly reduced family size since the late 1970's.

From a medical stand point, obesity contributes to a broad range of health issues, involving type 2 diabetes mellitus, cardiovascular and kidney diseases (see review by Barton), as well as certain cancers, etc ${ }^{[5]}$. It significantly increases mortality, causes physical impairment and psychological stigma, and results in economic burden that is largely unmanageable even in many affluent societies. Therefore, prevention and treatment of obesity are a common challenge with extraordinary urgency to both developed and developing nations, and allout efforts are required to exploit efficient strategies, from policy to education, from research to industry, and from physicians to patients.

Obesity is generally recognized as disturbances in energy homeostasis between nutrient intake and expenditure. The balance is controlled by the central nervous system (CNS),

\footnotetext{
* To whom correspondence should be addressed.

E-mail wangmw@mail.shcnc.ac.cn

Received 2011-12-07 Accepted 2011-12-08
}

mainly the neurons located in hypothalamus. They sense nutrient molecules in circulation and peripheral signaling proteins released by organs in order to regulate energy homeostasis $^{[6]}$. However, the exact molecular mechanisms relative to pathogenesis of obesity remain elusive (see review by Herbst), and may include interaction of different genes (see article by Ke et al), environmental factors, life style, social status and even intrauterine or neonatal nutritional states ${ }^{[7]}$. It is believed that a chronic, low grade inflammation, in response to excess nutrients or energy, in the metabolic tissues is involved in the development of obesity (see review by Gao and Ye). A cascade may exist starting from release of inflammatory cytokines [tumor necrosis factor (TNF)- $\alpha$, interleukin-1(IL-1) $\beta$, CCL2, etc] and activation of inflammatory kinases (JNK, IKK, PKR etc) by metabolic cells, progressing towards tissue malfunction (eg insulin resistance), and eventually linking inflammation to obesity-related diseases, such as type 2 diabetes $^{[8]}$.

While prevention is largely dependent upon change of life style, therapeutic approaches are dominated by medications that result in weight loss, covering both small molecules and peptides aiming at a variety of drug targets (Tables 1 and $2)^{[9-11]}$. Of which, sibutramine, phentermine, rimonabant, lorcaserin, contrave, qnexa, liraglutide, tesofensine and velneperit, etc, target the CNS and decrease energy intake via reducing appetite or increasing satiety, whereas orlistat and cetilistat interfere with nutrient absorption in the digestive system. Although the pipeline looks prosperous, only one drug (orlistat) is available at present for long-term weight control because sibutramine was withdrawn last year due to an increased cardiovascular risk ${ }^{[12]}$. Others that were approved for short-term treatment (eg phentermine, diethylpropion, benzphetamine and phendimetrazine) all have the limitation of controlled use because of potential drug abuse ${ }^{[13]}$.

With worldwide demands for a "magic bullet" to loose body weight, major pharmaceutical companies are chasing after the multibillion-dollar obesity market even under extremely high risks. In 2010, Sanofi-Avantis decided to discontinue all ongoing clinical trials and to suspend sales of its cannabinoid 
Table 1. Anti-obesity drugs approved, rejected, withdrawn or revised by the FDA.

\begin{tabular}{|c|c|c|c|}
\hline Drug & Company & Mechanism of action & Comments \\
\hline \multicolumn{4}{|c|}{ Anti-obesity drugs presently on the market } \\
\hline Orlistat & Roche, GSK & Pancreatic lipase inhibitor & Approved for long-term use in 1999 \\
\hline Phentermine & Not available & Adrenaline reuptake inhibitor & Schedule IV drug, approved for short-term use \\
\hline Diethylpropion & Not available & $\begin{array}{l}\text { Norepinephrine/dopamine releasing } \\
\text { stimulator }\end{array}$ & Schedule IV drug, approved for short-term use \\
\hline Benzphetamine & Pharmacia & $\begin{array}{l}\text { Norepinephrine/dopamine releasing } \\
\text { stimulator }\end{array}$ & Schedule III drug, approved for short-term use \\
\hline Phendimetrazine & Not available & $\begin{array}{l}\text { Norepinephrine/dopamine releasing } \\
\text { stimulator }\end{array}$ & Schedule III drug, approved for short-term use \\
\hline \multicolumn{4}{|c|}{ Anti-obesity drugs that await for decisions } \\
\hline Contrave & Orexigen & Bupropion+naltrexone & $\begin{array}{l}\text { The FDA requested data on long-term cardiovascular } \\
\text { risk assessment in } 2011\end{array}$ \\
\hline Qnexa & Vivus & Phentermine+topiramate & $\begin{array}{l}\text { The FDA requested data on teratogenic potential in } \\
2010\end{array}$ \\
\hline \multicolumn{4}{|c|}{ Anti-obesity drugs rejected by the FDA } \\
\hline Rimonabant & Sanofi-Aventis & CB1R antagonist & $\begin{array}{l}\text { Not approved in the USA due to its psychiatric side- } \\
\text { effects and withdrawn from the European market in } \\
2009 \text { for increased risk of serious psychiatric disorders }\end{array}$ \\
\hline Lorcaserin & Arena Pharma & Selective $5-\mathrm{HT}_{2 \mathrm{C}}$ receptor agonist & $\begin{array}{l}\text { Not approved due to concerns over carcinogenicity } \\
\text { observed in rats in } 2010\end{array}$ \\
\hline \multicolumn{4}{|c|}{ Anti-obesity drugs withdrawn from the market } \\
\hline $\begin{array}{l}\text { Fenfluramine and } \\
\text { dexfenfluramine }\end{array}$ & Wyeth-Ayerst & 5- $\mathrm{HT}_{2 \mathrm{~B}}$ receptor agonist & $\begin{array}{l}\text { Withdrawn after reports of valvular heart damage and } \\
\text { primary pulmonary hypertension in } 1997\end{array}$ \\
\hline Phenylpropanolamine & Not available & $\begin{array}{l}\text { Norepinephrine/dopamine releasing } \\
\text { stimulator }\end{array}$ & $\begin{array}{l}\text { Withdrawn for increased risk of hemorrhagic stroke in } \\
2000\end{array}$ \\
\hline Sibutramine & Abbott & NA/5-HT reuptake blocker & $\begin{array}{l}\text { Withdrawn for increased risk of cardiovascular events } \\
\text { in } 2010\end{array}$ \\
\hline
\end{tabular}

5-HT, 5-hydroxytryptamine; NA, noradrenaline; CB1R, cannabinoid 1 receptor; FDA, Food and Drug Administration; GSK, GlaxoSmithKline.

Table 2. A glance of new anti-obesity drugs in the pipeline.

\begin{tabular}{llll}
\hline \multicolumn{1}{c}{ Drug } & Company & \multicolumn{1}{c}{ Mechanism of action } \\
\hline Empatic & Orexigen & Bupropion+zonisamide & Phase III \\
Pramlintide & Amylin & Leptin analog + amylin analog & Phase III \\
Cetilistat & Alizyme/Takeda & Pancreatic lipase inhibitor & Phase III \\
Liraglutide & Novo Nordisk & Long-acting GLP-1 analog & Phase III \\
Tesofensine & NeuroSearch & NA/DA/5-HT reuptake inhibitor & Phase II \\
Velneperit & Shinogi & Neuropeptide Y5 receptor antagonist & Phase II \\
Obinepitide & 7TM & PPY3-36 and pancreatic polypeptide analog \\
LY377604 & Eli Lilly & B-3 adrenergic receptor agonist & Phase II \\
ZGN-433 & Zafgen & MetAP2 inhibitor & Phase II \\
PF-04971729 & Pfizer & SGLT2 inhibitor & Phase I \\
PF-04620110 & Pfizer & DGAT1 inhibitor & Phase I \\
GSK 598809 & GSK & D3 receptor antagonist \\
GSK 1521498 & GSK & H-opioid receptor antagonist \\
\hline
\end{tabular}

GLP-1, glucagon-like peptide-1; PPY3-36, peptide YY3-36; MetAP2, methionyl aminopeptidase 2; SGLT2, sodium glucose co-transporter type 2; DGAT1, diglyceride acyltransferase. 
1 receptor (CB1R) blocker, rimonabant, following the recommendation from the European Medicines Agency in response to serious psychiatric side-effects ${ }^{[14]}$. Merck and Pfizer wasted no time to cease the development of their versions of CB1R antagonists, taranabant and CP-945598, respectively, making CB1R as a drug target dubious. Thus, a new strategy to discover selective CB1R blockers that predominantly interact with the receptor in the periphery has been debated ${ }^{[14]}$.

Haunted by the withdrawal of sibutramine and the end of CB1R blockers, the developers of anti-obesity drugs experienced further setbacks. Apart from rejecting regulatory approval of Vivus's combination product qnexa and Arena's locaserin ${ }^{[15]}$, the Food and Drug Administration requested a cardiovascular outcome study for another combination therapy, Orexigen's contrave ${ }^{[10]}$. Obviously, the paramount concern on therapeutics against obesity is safety because it is not a fatal disease and requires long-term management. In comparison with physical exercise and diet control that demand for active participation, the advantage of a safe and efficacious pill is unquestionable albeit it is passive in terms of patient efforts.

The multi-facet actions of the gut hormone, glucagonlike peptide-1 (GLP-1), render it ideal as a target for drug intervention ${ }^{[16]}$. Encouraged by early success with a GLP-1 mimetic, exenatide, in diabetic weight loss ${ }^{[17]}$, liraglutide, a long-acting GLP-1 analog, was shown to reduce body weight in both animal models of obesity (see article by Hansen et al) and human clinical studies ${ }^{[18]}$. Similar effects in animal models were also seen with a non-peptidic GLP-1 receptor agonist Boc $5^{[19]}$ and one of its analogs (see review by He et al).

As demonstrated in the treatment of many other diseases, combination therapy is more effective than a single agent. Of the four such products (qnexa, contrave, empatic and pramlintide), qnexa and contrave were previously approved for other indications. Clinical trials revealed that qnexa (phentermine plus topiramate) and contrave (bupropion plus naltrexone) administration induced a net weight loss of $12.2 \mathrm{~kg}$ and 6.2 $\mathrm{kg}$, respectively, compared with a reduction of $4.0 \mathrm{~kg}$ or $3.2 \mathrm{~kg}$ when phentermine or bupropion was administered alone ${ }^{[10]}$.

Facing such an unprecedented challenge on a global scale, it is far from adequate in terms of novel approaches to obesity management. Clearly, the most important task lies in education that alters social behavior capable of preventing the prevalence of obesity from rising. In this special issue, several topics that relate to obesity etiology, animal models (see review by Nilsson et al), therapeutics and clinical implications are covered in order to provide a glance of the latest develop- ments in this important field.

\section{References}

1 Wang YF, Beydoun MA, Liang L, Caballero B, Kumanyika SK. Will all Americans become overweight or obese? Estimating the progression and cost of the US obesity epidemic. Obesity 2008; 16: 2323-30.

2 Finkelstein EA, Ruhm CJ, Kosa KM. Economic causes and consequences of obesity. Annu Rev Publ Health 2005; 26: 239-57.

3 Wu YF. Overweight and obesity in China. Br Med J 2006; 333: 362-3.

4 Cheng TO, Ji CY. Prevalence and geographic distribution of childhood obesity in China in 2005. Int J Cardiol 2008; 131: 1-8.

5 Dixon JB. The effect of obesity on health outcomes. Mol Cell Endocrinol 2009; 316: 104-8.

6 Friedman JM. Obesity causes and control of excess body fat. Nature 2009; 459: 340-2.

7 Zhang ZY, Zeng JJ, Kjaergaard M, Guan N, Raun K, Nilsson C, et al. Effects of a maternal diet supplemented with chocolate and fructose beverage during gestation and lactation on rat dams and their offspring. Clin Exp Pharmacol Physiol 2011; 38: 613-22.

8 Gregor MF, Hotamisligil GS. Inflammatory mechanisms in obesity. Annu Rev Immunol 2011; 29: 415-45.

9 Tseng YH, Cypess AM, Kahn CR. Cellular bioenergetics as a target for obesity therapy. Nat Rev Drug Discov 2010; 9: 465-81.

10 Powell AG, Apovian CM, Aronne LJ. New drug targets for the treatment of obesity. Clin Pharmacol Ther 2011; 90: 40-51.

11 Caveney E, Caveney BJ, Somaratne R, Turner JR, Gourgiotis L. Pharmaceutical interventions for obesity: a public health perspective. Diabetes Obes Metab 2011; 13: 490-7.

12 Sayburn A. Withdrawal of sibutramine leaves European doctors with just one obesity drug. Br Med J 2010; 340: c477.

13 Bray GA. Drug insight: appetite suppressants. Nat Clin Pract Gastroenterol Hepatol 2005; 2: 89-95.

14 Bifulco M, Pisanti S. End of the line for cannabinoid receptor 1 as an anti-obesity target? An opinion. Nat Rev Drug Discov 2009; 8: 594.

15 Jones D. Suspense builds on anti-obesity rollercoaster ride. Nat Rev Drug Discov 2011; 10: 5-6.

16 Small CJ, Bloom SR. Gut hormones as peripheral anti obesity targets. Curr Drug Targets CNS Neurol Disord 2004; 3: 379-88.

17 Defronzo RA, Ratner RE, Han J, Kim DD, Fineman MS, Baron AD. Effects of exenatide (exendin-4) on glycemic control and weight over 30 weeks in metformin-treated patients with type 2 diabetes. Diabetes Care 2005; 28: 1092-100.

18 Astrup A, Rossner S, Van Goal L, Rissanen A, Niskanen L, Al Hakim M, et al. Effects of liraglutide in the treatment of obesity: a randomised, double-blind, placebo-controlled study. Lancet 2009; 374: 1606-16.

19 He M, Su HR, Gao WW, Johansson SM, Liu Q, Wu XY, et al. Reversal of obesity and insulin resistance by a non-peptidic glucagon-like peptide-1 receptor agonist in diet-induced obese mice. PLOS ONE 2010; 5: e14205. 